\title{
Beden Eğitimi Öğretmeni Adaylarının “İdeal Beden Eğitimi Öğretmeni Nitelikleri” İle İlgili Görüşleri
}

\section{Physical Education Teacher Candidates'Views on Ideal Physical Education Teacher Qualifications}

\author{
Aylin Çelen, ${ }^{\mathrm{a}^{*}}$ Devrim Bulut ${ }^{\mathrm{b}}$ \\ ${ }^{a}$ Dr. Öğr. Üyesi, Abant İzzet Baysal Üniversitesi, Beden Eğitimi ve Spor Yüksekokulu, Beden Eğitimi Öğretmenliği Bölümü, 14280, Bolu/Türkiye. \\ ORCID: 0000-0001-7299-8306 \\ ${ }^{\text {b} A r s ̧ . ~ G o ̈ r . ~ D r ., ~ A b a n t ~ I ̇ z z e t ~ B a y s a l ~ U ̈ n i v e r s i t e s i, ~ B e d e n ~ E g ̆ i t i m i ~ v e ~ S p o r ~ Y u ̈ k s e k o k u l u, ~ S p o r ~ Y o ̈ n e t i c i l i g ̆ i ~ B o ̈ l u ̈ m u ̈, ~ 14280, ~ B o l u / T u ̈ r k i y e . ~}$ \\ ORCID: 0000-0001-8871-6182
}

\section{MAKALE BILGİSI}

\section{Makale Geçmişi:}

Başvuru tarihi: 27 Eylül 2018

Düzeltme tarihi: 28 Ekim 2018

Kabul tarihi: 20 Kasim 2018

\section{Anahtar Kelimeler:}

Beden eğitimi

Beden eğitimi öğretmeni adayları

İdeal beden eğitimi öğretmeni
ÖZ

$\mathrm{Bu}$ araştırma, beden eğitimi öğretmeni adaylarının ideal beden eğitimi öğretmeni niteliklerine ilișkin görüşlerini belirlemek amacıyla yapılmıștır. Araștırmada tarama modeli kullanılmıștır. Çalışma grubunu Abant İzzet Baysal Üniversitesi, Beden Eğitimi ve Spor Yüksekokulu, Beden Eğitimi Öğretmenliği Bölümü’nde öğrenim gören 163 öğretmen adayı oluşturmaktadır. Çalışmada veri toplama aracı olarak Çoban ve Turan (2006) tarafindan geliştirilen "İdeal Beden Eğitimi Öğretmeninin Nitelikleri Ölçeği” kullanılmıştır. Çalışma bulgularına göre öğretmen adaylarının ideal beden eğitimi öğretmeninin nitelikleri ölçeğinden elde ettikleri puanlar cinsiyet değişkenine göre karşılaştırıldığında istatistiksel olarak anlamlı bir farka rastlanmamıştır. Fakat öğretmen adaylarının puanları arasında sınıf seviyesi değișkenine göre istatistiksel olarak anlamlı bir fark bulunmuştur. Sonuç olarak araştırmada, beden eğitimi öğretmeni adaylarının genel olarak ideal bir beden eğitimi öğretmeninin sahip olması gereken niteliklerin çoğunun farkında oldukları belirlenmiştir.

\section{A B S T R A C T}

The purpose of this study was to determine physical education teacher candidates' views on ideal physical education teacher qualifications. Survey model was used in this study. The sample group was composed of 163 teacher candidates from Abant Izzet Baysal University, Department of Physical Education Teacher. The data were collected by using "Ideal Physical Education Teacher Qualifications Scale" which was developed by Coban and Turan (2006). As a result of the study, it was found that there was no statistically significant difference between the physical education teacher candidates' scores according to the gender variable. However, there was a statistically significant difference between the scores of teacher candidates according to the class level variable. In addition to the study results, it was determined that physical education teacher candidates are generally aware of most of the qualifications that an ideal physical education teacher should have.

\section{Giriş}

Toplumların yetiştirdiği bireylerin gelişimi eğitime bağlıdır. Mugenda ve Mugenda (1999)'ya göre eğitim, geniş çapta insan haklarının temel kanunu olarak kabul edilen, sağlık ve gücün bir kaynağı ve aydınlanmanın anahtarı olarak tanımlanır (Akt: Kosgei, Jairo, Odera ve Ayugi, 2013). Eğitimin başarılı ve nitelikli olabilmesi için içerdiği tüm unsurların üst düzey niteliğe ve donanıma sahip olması
(Taşkaya, 2012) ve bunun yanında eğitim unsurlarından biri olan öğretmenlik mesleğinin de doğru orantılı olarak nitelikli ve donanımlı olması beklenmektedir. Milli Eğitim Temel kanununda (2012) öğretmenlik ifadesi "Devletin eğitim, öğretim ve bununla ilgili yönetim görevlerini üzerine alan özel bir ihtisas mesleği” olarak tanımlanmaktadır.

Öğretmenlerde aranan niteliklerin ve yeterliklerin belirlenmesi Milli Eğitim Bakanlığı'nca yapılmaktadır. 9

*Sorumlu yazar/Corresponding author

e-posta: aylin_celen@hotmail.com.tr 
Haziran 2017 tarihinde Öğretmen Strateji Belgesi’nde öğretmen yeterliklerinin ihtiyaçlar doğrultusunda güncellenmesi kararı alınmış ve Milli Eğitim Şûraları'nda pek çok kez bu konuya vurgu yapılmıştır. 2015-2019 MEB Stratejik Planı ise, öğretmenlik mesleki gelişimine yönelik Okul Temelli Mesleki Gelişim Modeli (OTMG)'nin yaygınlaştırılması, hizmet içi planlamalarında öğretmen yeterliklerinin dikkate alınması gibi hedeflere yer verilmiştir (MEB, 2017).

Nitelikli öğretmen yetiştirilmesi hususunda MEB'in yanı sıra yapılan araştırmalar da konunun önemime vurgu yapmaktadır. Çetin (2001), iyi bir öğretmende aranan nitelikleri zihinsel yeterlik, alan bilgisi, akademik hazırlık, gelişim ve öğrenim bilgisi ile istenilir kişilik özellikleri olarak ifade etmiştir. Bunun yanı sıra Erden (1998)etkili bir öğretmende olması gereken özellikleri, kişisel ve mesleki boyutta incelerken; Komarraju (2013) öğrenci motivasyonu için ideal öğretmen özellikleri üzerine yaptığı araştırmasında öğretmenin kişisel özelliği olarak şefkatli, sempatik, bilgili, kendinden emin ve cesaretlendirici olması gerektiğini; bir diğer araştırma "İdeal öğretmen kimdir?" sorusu üzerine, ideal öğretmenin sahip olması gereken iki büyük özelliğin varlığı üzerinde durarak bunlardan ilkinin kişisel özellikler, diğerinin ise konu öğretimi bilgisi (Arnon ve Reichel, 2007) olduğunu ifade etmişlerdir. Walker (2008) ise araştırmasının sonucunda nitelikli aday öğretmenlerde bulunması gereken özellikleri; pozitif, ileri dönük, beklenti sahibi, yaratıcı, adil, bireysel donanım sahibi, aidiyet hissine sahip, şefkatli, esprili, saygılı, affedici ve yanlışlarını kabullenen şeklinde 12 başlık altında toplamıştır.

Nitelikli, üretken, çağdaş, günümüz gereksinimlerini karşılayan, bilim ve sanata değer veren, milli ve manevi değerlerimizi kavramış bireyler yetiştirmek için, aynı zamanda öğretmenlerin de kendi nitelik ve yeterliliklerinin farkında olması ve bunları devamlı geliştirme çabası içinde olması gerekmektedir (Karabulutlu ve Pulur, 2017).

Öğretmenlik mesleğinin kalitesinin artırılması, ilk önce öğretmenlerde bulunması gereken nitelik ve yeterliklerin tespit edilmesi ve bu nitelik ve yeterliklerin, öğretmen adaylarına kazandırılması ile mümkündür. Çünkü eğitim ve öğretimin sürecinin tüm boyutlarıyla aktif ve verimli bir yapıya sahip olması, ancak bu süreçte önemli bir rol üstlenen öğretmenlerin mesleğin gerektirdiği nitelikleri ve yeterlikleri yerine getirmeleri ile mümkün olabilecektir.

Her öğretmenlik branşının toplum fertlerinin yetiştirilmesinde önemli bir rolü vardır. Eğitimin tamamlayıcısı ve ayrılmaz bir parçası olan beden eğitimi öğretmenliği de sağlıklı, yapıcı, yaratıcı, üretken, mutlu, iyi ahlaklı ve dengeli bir kişilik eğitiminde, beden ve ruh sağlığının iyileştirilmesinde gerekli olan branş alanlarından biridir (Dinçer, 2012) Milli Eğitim Temel Kanunu'nda (2012) eğitimin genel amaçlarından biri “Türk Milleti'nin bütün fertlerini, beden, zihin, ahlak, ruh ve duygu bakımlarından dengeli ve sağlıklı şekilde gelişmiş bir kişiliğe ve karaktere, hür ve bilimsel düşünme gücüne, geniş bir dünya görüşüne sahip, insan haklarına saygıll, kişilik ve teşebbüse değer veren, topluma karşı sorumluluk duyan; yapıcı, yaratıcı ve verimli kişiler yetiştirmek" olarak ifade edilmektedir. Bu bağlamda genel eğitimin bir parçası olan beden eğitiminin önemi, kanunun bu maddesinde de ayrıca vurgulanmaktadır. Başar ve Coşkun (2017)'un yapmış oldukları araştırmada, beden eğitimi ve spor derslerinin en az diğer dersler kadar eşit oranda önem arz ettiğini ve öğrencilerinin psikomotor becerileri gelişimi yanında bilişsel, duygusal ve sosyal beceriler kazandıklarını ifade ederek bu dersin önemine dikkat çekmektedir. Aynı zamanda günümüz beden eğitimi öğretmenliği mesleğinin, mesleki eğitimlerinin yanı sıra, özel alan yeterliklerine sahip olmasının hem öğretmenler, hem de öğrenciler açısından önem taşıdığ 1 söylenebilir (Karabulutlu ve Pulur, 2017).

Öğretmenin davranış ve kişiliği, öğrencilerin sınıftaki davranışlarını ve kişilik gelişimini etkiler (Solakumur, Kul, Ünlü ve Mülhim, 2017). Saçlı, Bulca, Demirhan ve Kangalgil (2009)'in yapmış oldukları araştırmada beden eğitimi öğretmenleri için önerilen kişisel niteliklerden ilk üçünü "eleştiriye açık olma”, "öğrenciyi her konuda anlama" ve "geniş bakış açısına sahip olma"; Taşkaya (2012) ise anlayışlı olma, öğrenciye eşit davranma, kendini geliştirme olarak ifade etmişlerdir. Aynı şekilde, bir beden eğitimi öğretmenin kişiliği ve sergilediği davranışlar öğrencilerin beden eğitimi dersine olan ilgilerini ve başarılarını da etkilemektedir (Çoban ve Turan, 2006). Beden eğitimi öğretmeni derse başlamadan önce dersin ön hazırlıklarını tamamlamalı, araç gereçlerini temin etmeli, etkinlikleri çeşitlendirmeyi bilmeli, zaman yönetimine hâkim olmalı ve özellikle öğrencilerin bireysel farklılıklarını göz önünde bulundurmalıdır. Bu durum, beden eğitimi öğretmeninin kişisel nitelikler kadar sınıf içinde kullanılan öğretim stratejilerine de önem vermesi gerektiğinin göstergesidir.

Öğretmenlerin mesleki ve öğretimsel özellikleri aldıkları eğitim ile doğru orantılıdır. Beden eğitimi öğretmenlerinin yetiştirilmesinde Spor Bilimleri Fakülteleri, Beden Eğitimi ve Spor Yüksekokulları ve ayrıca bazı üniversitelerde Eğitim Fakülteleri içerisinde yer alan birimler de beklenilen nitelikte öğretmen yetiştiren kurumlardır. $\mathrm{Bu}$ kurumlarda öğrenim gören öğrenciler aday öğretmen olarak öğrenimleri boyunca edindikleri yaşantıları uygulama firsatı bulmaktadır. $\mathrm{Bu}$ firsatlar beden eğitimi öğretmen adaylarının gelişimi ve kendilerini mesleki yaşama hazırlama konusunda önem arz etmektedir.

Lisans eğitimleri boyunca mesleki yaşantılarına hazırlanan beden eğitimi öğretmeni adayları, edindikleri tecrübeleri ile ideal öğretmen olma nitelikleri hakkında bir takım görüşlere sahip olmaktadır. Öğretmen adaylarının ideal öğretmen nitelikleri ile ilgili sahip oldukları bu görüşlerinin belirlenmesi son derece önem arz etmektedir. Bu görüşler doğrultusunda bir beden eğitimi öğretmenin sahip olması gereken nitelikler ile öğrencilerin kendi görüşleri arasındaki farklar ortaya çıkabilir. Bu farkların oluşması durumunda öğretim elemanlarının lisans eğitimi süresince verilen derslerin içeriğinde değişikliklere gitmesi ve öğretmen adaylarının ideal bir beden eğitimi öğretmeninin sahip olması gereken nitelikler konusunda bilgilendirilmeleri gerekmektedir. Bu bağlamda bu araştırmanın; beden eğitimi öğretmen adaylarının ideal beden eğitimi öğretmeni nitelikleri ile ilgili görüşlerinin belirlenmesi açısından önemli olduğu düşünülmektedir.

$\mathrm{Bu}$ araştırma, beden eğitimi öğretmen adaylarının ideal beden eğitimi öğretmeni nitelikleri ile ilgili görüşlerini 
belirleyebilmek amacıyla yapılmıştır. $\mathrm{Bu}$ amaç altında aşağıdaki sorulara yanıt aranmıştır:

(i) Öğretmen adaylarının ideal bir beden eğitimi öğretmeninin sahip olması gereken niteliklere yönelik görüşleri nasıldır?

(ii) Araştırmaya katılan öğretmen adaylarının ideal beden eğitimi öğretmeni niteliklerine ilişkin görüşleri; cinsiyet ve öğrenim görmekte oldukları sınıf seviyesi değişkenlerine göre istatistiksel olarak anlamlı bir farklılık göstermekte midir?

\section{Yöntem}

$\mathrm{Bu}$ bölümde, çalışmada kullanılan araştırma modeli, çalışma grubu, veri toplama aracı, verilerin toplanması ve analizi hakkında bilgi verilmiştir.

\subsection{Araştırma Modeli}

$\mathrm{Bu}$ araştırmada, beden eğitimi öğretmen adaylarının ideal beden eğitimi öğretmeni niteliklerine ait görüşlerini belirleyebilmek için tarama modeli kullanılmıştır.Karasar (2013) tarama modellerinin, geçmişte ya da halen varolan bir durumu, varolduğu şekliyle betimlemeyi amaçlayan araştırma yaklaşımları olduğunu ifade etmektedir.

\section{2. Çalışma Grubu}

Çalışma grubunu Abant İzzet Baysal Üniversitesi, Beden Eğitimi ve Spor Yüksekokulu, Beden Eğitimi Öğretmenliği Bölümü'nde 2017-2018 eğitim-öğretim yılı bahar döneminde öğrenim görmekte olan 163 öğretmen aday1 oluşturmaktadır. Çalışma grubunun seçiminde "kolay ulaşılabilir durum örnekleme yöntemi” kullanılmıştır. Kolay ulaşılabilir durum örnekleme yöntemi ile araştırmacı yakın ve erişilmesi kolay bir durum seçtiği için, bu örnekleme yöntemi araştırmacıya hız ve pratiklik kazandırır (Yıldırım ve Şimşek, 2005).

Çalışmaya katılan öğretmen adaylarının yaş aralığı 18 ile 29 arasında değişmekte olup grubun yaş ortalaması $20.89 \pm$ 1.92'dir. Çalışmaya katılan öğretmen adaylarının cinsiyet ve sınıf değişkeni hakkındaki bilgiler Tablo 1'de verilmiştir.

Tablo 1.Beden Eğitimi Öğretmeni Adaylarının Cinsiyet ve Öğrenim Görmekte Oldukları Sınıf Dağılımı

\begin{tabular}{lcccccc}
\hline & \multicolumn{2}{c}{ Kadin } & \multicolumn{2}{c}{ Erkek } & \multicolumn{2}{c}{ Toplam } \\
\hline & $\mathrm{f}$ & $\%$ & $\mathrm{f}$ & $\%$ & $\mathrm{f}$ & $\%$ \\
\hline 1.Sinıf & 15 & 9,2 & 26 & 16,0 & 41 & 25,2 \\
2.Sinif & 17 & 10,4 & 26 & 16,0 & 43 & 26,4 \\
3.Sinif & 15 & 9,2 & 25 & 15,3 & 40 & 24,5 \\
4.Sinif & 16 & 9,8 & 23 & 14,1 & 39 & 23,9 \\
\hline Toplam & 63 & 38,6 & 100 & 61,4 & 163 & 100 \\
\hline
\end{tabular}

Tablo 1 incelendiğinde çalışma grubunu oluşturan öğretmen adaylarının 63'ünün kadın ve 100'ünün ise erkek olduğu görülmektedir. Ayrıca çalışmada yer alan öğretmen adaylarının \%25,2'si birinci sınıfta, \%26,4'ü ikinci sınıfta, $\% 24,5$ 'i üçüncü sinıfta ve \%23,9'u ise dördüncü sinıfta öğrenim görmektedir.

\subsection{Veri Toplama Arac1}

Veri toplama aracı olarak araştırmacı tarafından hazırlanan kişisel bilgi formu ve ideal beden eğitimi öğretmeni nitelikleri ölçeği kullanılmıştır.

Kişisel Bilgi Formu: Çalışmaya katılan öğretmen adaylarının cinsiyet ve öğrenim görmekte oldukları sınıf bilgilerinin belirlenebilmesi için araştırmacılar tarafından hazırlanan kişisel bilgi formu kullanılmıştır.

İdeal Beden Eğitimi Öğretmeni Nitelikleri Ölçeği: Beden eğitimi öğretmeni adaylarının ideal beden eğitimi öğretmeni niteliklerine yönelik görüşlerini belirlemek amacı ile Çoban ve Turan (2006) tarafindan geliştirilen "İdeal Beden Ĕgitimi Öğretmeninin Nitelikleri Ölç̧ĕ̌i" kullanılmıştır. Ölçeğin Cronbach Alfa güvenirlik katsayısı 0.96 'dır. Beşli likert tipi olan ölçekte toplam 64 madde bulunmaktadır. Ölçekte, 5 "tamamen katılıyorum", 4 "katıliyorum", 3 "kismen katıllyorum", 2 "katılmıyorum" ve 1 "hiç katılmıyorum" şeklinde puanlanmaktadır. Ölçek; konu alan hâkimiyeti (KAH): bilişsel ve psikomotor boyut, öğretmenlik meslek bilgisi (ÖMB): sinıf yönetimi ve iletişim, öğretimi planlama ve öğretim yöntem teknikleri, araç-gereç (öğretim materyali) kullanımı, ölçme ve değerlendirme, beden eğitimi ile ilgili genel kültür ve genel kültür olmak üzere 8 alt boyuttan oluşmaktadır. Ölçeğin bu çalışma için hesaplanan Cronbach Alfa güvenirlik katsayısı ise 0.97 olarak bulunmuştur.

\subsection{Verilerin Toplanmasi}

Araştırmada yer alan öğretmen adaylarına, çalışmada kullanılan "İdeal Beden Eğitimi Öğretmeninin Nitelikleri Ölçeği" araştırmacılardan biri tarafından elden dağıtılmıştır. Ölçeğin dağıtılması sonrasında ölçek ile ilgili gerekli açıklamalar yapılmıştır. Öğretmen adayları tamamen gönüllük esasına dayalı olarak çalışmaya katılmışlardır.

\subsection{Verilerin Analizi}

Elde edilen verilerin çözümlenmesinde frekans, yüzde, ortalama, standart sapma, bağımsız gruplar t testi ve tek yönlü varyans analizi işlemlerinden yararlanılmıştır. Elde edilen veriler için kullanılan istatistikî işlemlerde SPSS 17,0 paket programı kullanılmıştır.

\section{Bulgular ve Yorumlar}

Çalışmaya katılan beden eğitimi öğretmeni adaylarının ideal beden eğitimi öğretmeni nitelikleri ölçeğinin alt boyutlarından ve ölçeğin tamamından aldıkları puanların ortalama ve standart sapmaları Tablo 2'de sunulmuştur. Her alt boyutun içerdiği ifade sayısı farklı olduğundan tabloda yer alan ortalamaların anlaşılabilir olabilmesi ve karşılaştırma yapılabilmesi için, alt boyutlardaki toplam puanlar ilgili alt boyutta yer alan ifade sayısına bölünerek ve ölçeğe ait toplam puan ortalaması ise, ölçekten alınan toplam puanın ölçekte yer alan ifade sayısına (64) bölünerek tüm ortalamalar 5 üzerinden sunulmuştur.

Tablo 2.Beden Eğitimi Öğretmeni Adaylarının İdeal Beden Eğitimi Öğretmeni Nitelikleri Ölçeği'nden Aldıkları Puanlara Ait Betimsel İstatistik Tablosu 


\begin{tabular}{lcl}
\hline Alt Boyutlar & $\mathrm{n}$ & $\overline{\mathrm{X}}_{ \pm \mathrm{ss}}$ \\
\hline KAH: Bilişsel Boyut (Teorik) & 163 & $4,50 \pm 0,48$ \\
KAH: Psikomotor Boyut (Uygulama) & 163 & $4,64 \pm 0,51$ \\
ÖMB: Sınıf Yönetimi ve İletişim & 163 & $4,62 \pm 0,47$ \\
ÖMB: Öğretimi Planlama ve Öğretim & 163 & $4,60 \pm 0,46$ \\
Yöntem Teknikleri & & \\
ÖMB: Araç-Gereç Kullanımı & 163 & $4,58 \pm 0,54$ \\
ÖMB: Ölçme ve Değerlendirme & 163 & $4,61 \pm 0,50$ \\
Beden Eğitimi İle İlgili Genel Kültür & 163 & $4,66 \pm 0,49$ \\
Genel Kültür & 163 & $4,69 \pm 0,44$ \\
Toplam & 163 & $4,61 \pm 0,39$ \\
\end{tabular}

Tablo 2 incelendiğinde çalışmaya katılan öğretmen adaylarının, ölçeğin alt boyutları ve toplamından aldıkları puan ortalamaları göz önünde bulundurulduğunda; öğretmen adaylarının ideal bir beden eğitimi öğretmeninin sahip olması gereken nitelikler olarak tüm alt boyutların son derece gerekli olduğunu belirttikleri söylenebilir. Tüm alt boyut ortalamalarının çok yüksek olmasına rağmen, ortalamalar kendi içinde kıyaslandığında, öğretmen adayları ideal bir beden eğitimi öğretmeninin en çok "genel kültür" ve "beden eğitimi ile ilgili genel kültür"e sahip olması gerektiğini düşünürken, en az ise "konu alanı hakimiyeti: bilişsel boyut”a sahip olmaları gerektiğini belirtmişlerdir.

Öğretmen adaylarının ideal beden eğitimi öğretmeninin sahip olması gereken nitelikler ile ilgili görüşlerinin cinsiyet değişkenine göre farklılaşıp farklılaşmadığ bağımsız gruplar $t$ testi ile karşılaştırılmış ve bulgular Tablo 3'te sunulmuştur.

Tablo 3.Beden Eğitimi Öğretmeni Adaylarının İdeal Beden Eğitimi Öğretmeni Nitelikleri İle İlgili Görüşlerinin Cinsiyet Değişkenine Göre Karşılaştırılması

\begin{tabular}{|c|c|c|c|c|c|c|}
\hline \multirow[b]{2}{*}{ Alt Boyutlar } & \multicolumn{2}{|c|}{ Kadın } & \multicolumn{2}{|c|}{ Erkek } & \multirow[b]{2}{*}{$\mathrm{T}$} & \multirow[b]{2}{*}{$\mathrm{p}$} \\
\hline & $\mathrm{n}$ & $\bar{X}_{ \pm s s}$ & $\mathrm{n}$ & $\overline{\bar{X}}_{\underline{ \pm s s}}$ & & \\
\hline $\begin{array}{l}\text { KAH: } \\
\text { Bilişsel } \\
\text { Boyut } \\
\text { (Teorik) }\end{array}$ & 63 & $4,49 \pm 0.42$ & 100 & $4,51 \pm 0,51$ & ,281 &, 779 \\
\hline $\begin{array}{l}\text { KAH: } \\
\text { Psikomotor } \\
\text { Boyut } \\
\text { (Uygulama) }\end{array}$ & 63 & $4,71 \pm 0.37$ & 100 & $4,59 \pm 0.58$ & $-1,477$ & , 142 \\
\hline $\begin{array}{l}\text { ÖMB: Sinıf } \\
\text { yönetimi ve } \\
\text { iletişim }\end{array}$ & 63 & $4,65 \pm 0,34$ & 100 & $4,59 \pm 0,54$ &,- 786 & ,433 \\
\hline $\begin{array}{l}\text { ÖMB: } \\
\text { Öğretimi } \\
\text { planlama ve } \\
\text { öğretim } \\
\text { yöntem } \\
\text { teknikleri }\end{array}$ & 63 & $4,61 \pm 0,45$ & 100 & $4,61 \pm 0,47$ &,- 060 & ,952 \\
\hline $\begin{array}{l}\text { ÖMB: Araç- } \\
\text { gereç } \\
\text { kullanımı }\end{array}$ & 63 & $4,59 \pm 0,46$ & 100 & $4,57 \pm 0,59$ &,- 289 &, 773 \\
\hline $\begin{array}{l}\text { ÖMB: Ölçme } \\
\text { ve değer. }\end{array}$ & 63 & $4,65 \pm 0,39$ & 100 & $4,60 \pm 0,56$ &,- 640 &, 523 \\
\hline
\end{tabular}

\begin{tabular}{|c|c|c|c|c|c|c|}
\hline $\begin{array}{l}\text { Beden } \\
\text { eğitimi ile } \\
\text { ilgili genel } \\
\text { kültür }\end{array}$ & 63 & $4,67 \pm 0,40$ & 100 & $4,65 \pm 0,54$ &,- 235 &, 814 \\
\hline Genel kültür & 63 & $4,68 \pm 0,44$ & 100 & $4,70 \pm 0,43$ & ,284 & ,777 \\
\hline Toplam & 63 & $4,63 \pm 0,31$ & 100 & $4,60 \pm 0,44$ &,- 464 & 643 \\
\hline
\end{tabular}

Tablo 3 incelendiğinde, beden eğitimi öğretmeni adaylarının ideal beden eğitimi öğretmeninin nitelikleri ölçeğinin tüm alt boyutlarından ve ölçeğin tümünden elde ettikleri puanlar karşılaştırıldığında kadın ve erkek adaylar arasında istatistiksel olarak anlamlı bir farka rastlanmamıştır $(p>0.05)$. Bir başka ifadeyle, kadın ve erkek öğretmen adayların ideal bir beden eğitimi öğretmeninin sahip olması gereken nitelikler ile ilgili görüşleri birbirine benzerdir.

Beden eğitimi öğretmeni adaylarının ideal beden eğitimi öğretmeninin sahip olması gereken nitelikler ile ilgili görüşlerinin sınıf değişkeni açısından ele alındığında farklılık gösterip göstermediği tek yönlü varyans analizi yapılarak belirlenmiş ve bulgular Tablo 4 'te verilmiştir.

Tablo 4.Beden Eğitimi Öğretmeni Adaylarının İdeal Beden Eğitimi Öğretmeni Nitelikleri ile İlgili Görüşlerinin Sınıf Değişkeni Açısından Karşılaştırılması

\begin{tabular}{|c|c|c|c|c|c|c|}
\hline & & $\begin{array}{l}\text { Kareler } \\
\text { Top. }\end{array}$ & $\mathrm{sd}$ & $\begin{array}{c}\text { Kareler } \\
\text { Ort. }\end{array}$ & $\mathrm{F}$ & $\mathrm{p}$ \\
\hline \multirow[t]{2}{*}{$\begin{array}{l}\text { KAH: Bilişsel } \\
\text { Boyut } \\
\text { (Teorik) }\end{array}$} & $\begin{array}{l}\text { G.A. } \\
\text { G.İ. }\end{array}$ & 34,476 & 159 & ,839 & 3,870 &, $010^{*}$ \\
\hline & Top. & 36,993 & 162 & & & \\
\hline \multirow{3}{*}{$\begin{array}{l}\text { KAH: } \\
\text { Psikomotor } \\
\text { Boyut } \\
\text { (Uygulama) }\end{array}$} & G.A. & 2,241 & 3 & ,747 & & \\
\hline & G.İ. & 40,033 & 159 &, 252 & 2,967 &, $034^{*}$ \\
\hline & Top. & 42,274 & 162 & & & \\
\hline \multirow{3}{*}{$\begin{array}{l}\text { ÖMB: Sınıf } \\
\text { Yönetimi ve } \\
\text { İletişim }\end{array}$} & G.A. &, 823 & 3 & ,274 & & \\
\hline & G.İ. & 34,816 & 159 & ,219 & 1,253 & ,293 \\
\hline & Top. & 35,639 & 162 & & & \\
\hline ÖMB: & G.A. & 1,163 & 3 & ,388 & & \\
\hline $\begin{array}{l}\text { Oggretimi } \\
\text { Planlama ve } \\
\text { Öğretim }\end{array}$ & G.İ. & 32,719 & 159 & ,206 & 1,883 & ,135 \\
\hline $\begin{array}{l}\text { Yöntem } \\
\text { Teknikleri }\end{array}$ & Top. & 33,882 & 162 & & & \\
\hline \multirow{3}{*}{$\begin{array}{l}\text { ÖMB: Araç- } \\
\text { Gereç } \\
\text { (Öğretim } \\
\text { Materyali) } \\
\text { Kullanımı }\end{array}$} & G.A. & 1,003 & 3 & ,334 & & \\
\hline & G.İ. & 46,460 & 159 & ,292 & 1,144 &, 333 \\
\hline & Top. & 47,463 & 162 & & & \\
\hline \multirow{3}{*}{$\begin{array}{l}\text { ÖMB: Ölçme } \\
\text { ve } \\
\text { Değerlendirme }\end{array}$} & G.A. & ,552 & 3 &, 184 & & \\
\hline & G.İ. & 39,789 & 159 &, 250 &, 735 &, 533 \\
\hline & Top. & 40,341 & 162 & & & \\
\hline \multirow{3}{*}{$\begin{array}{l}\text { Beden Eğitimi } \\
\text { ile İlgili Genel } \\
\text { Kültür }\end{array}$} & G.A. & ,834 & 3 & ,278 & & \\
\hline & G.İ. & 38,160 & 159 &, 240 & 1,158 & ,328 \\
\hline & Top. & 38,994 & 162 & & & \\
\hline
\end{tabular}




\begin{tabular}{lcccccc}
\hline Genel Kültür & G.A. &, 487 & 3 &, 162 & & \\
& G.İ. & 30,266 & 159 &, 190 &, 853 &, 467 \\
& Top. & 30,753 & 162 & & & \\
\hline Toplam & G.A. &, 916 & 3 &, 305 & & \\
& G.İ. & 23,769 & 159 &, 149 & 2,043 &, 110 \\
& Top. & 24,685 & 162 & & & \\
& & & & & &
\end{tabular}

$* \mathrm{p}<0,05$

Tablo 4 incelendiğinde beden eğitimi öğretmeni adaylarının, öğrenim görmekte oldukları sınıf değişkeni açısından, ideal beden eğitimi öğretmeni nitelikleri ile ilgili görüşleri karşılaştırıldığında konu alanı hâkimiyeti: bilişsel boyut ve konu alanı hâkimiyeti: psikomotor boyutta istatistiksel olarak anlamlı bir farka rastlanmıştır $(\mathrm{p}<0,05)$. Ortaya çıkan bu anlamlı farkın hangi sınıf düzeyleri arasında olduğunu belirleyebilmek için Tukey analizi yapılmış ve her iki alt boyutta da farkın birinci ve dördüncü sınıflar arasında dördüncü sınıflar lehine olduğu ortaya çıkmıştır. Sınıflar arasında ortalamalar karşılaştırıldığında; konu alanı hâkimiyeti: bilişsel boyutta birinci sınıf öğrencilerinin ortalaması 4,32+0,49 iken dördüncü sınıf öğrencilerinin ortalamasının 4,66+0,39; konu alanı hâkimiyeti: psikomotor boyutta birinci sınıf öğrencilerinin ortalaması 4,46+0,49 iken dördüncü sınıf öğrencilerinin ortalamasının $4,79 \pm 0,26$ olduğu belirlenmiștir. Diğer alt boyut ve ölçeğin toplam puanlarının sınıf değişkeni açısından karşılaştırılmasında ise istatistiksel olarak anlamlı bir farka rastlanmamıştır ( $\mathrm{p}>0,05)$.

\section{Tartıșma, Sonuç ve Öneriler}

Beden eğitimi öğretmeni adaylarının ideal beden eğitimi öğretmeni özellikleri ile ilgili görüşlerinin incelendiği bu araştırmada, genel bir değerlendirme yapıldı ğında öğretmen adaylarının ideal bir beden eğitimi öğretmeninin sahip olması gereken özelliklerin tümüne "katılıyorum" ile "tamamen katılıyorum" yanıtlarını verdikleri belirlenmiştir. Bir başka ifadeyle, bir beden eğitimi öğretmeninin bilişsel ve psikomotor konu alanı hâkimiyeti, sınıf yönetimi, öğretimi planlama, öğretim yöntem ve teknikleri, araçgereç kullanımı, ölçme ve değerlendirme, genel kültür ve beden eğitimi ile ilgili genel kültür vb. bilgi ve becerilerine sahip olması gerektiği tüm beden eğitimi öğretmeni adayları tarafından bilinmektedir. Beden eğitimi öğretmeni adaylarının ideal beden eğitimi öğretmeninin sahip olması gereken niteliklerin farkında olmaları, öğretmen olduklarında bu özellikleri hayata geçirmeleri yönünden umut vericidir. Bir beden eğitimi öğretmeni bu özelliklere sahip oldukça etkili bir beden eğitimi öğretimi gerçekleştirebilecek ve bu sayede beden eğitimi ve spor anlamında daha bilinçli ve daha donanımlı kuşaklar yetiştirebilecektir. Ayrıca öğretmen adaylarından özellikle birinci ve ikinci sınıf ögrrencilerinin genel olarak ideal beden eğitimi öğretmeni niteliklerini bilmeleri, beden eğitimi öğretmenliği bölümlerini bilinçli olarak tercih ettiklerinin bir göstergesi olabilir. Araştırmanın bu bulgusu, Çalışkan, Işık ve Saygın (2013)'ın öğretmen adaylarının ideal öğretmen algılarını belirledikleri araştırmasındaki bulgular ile birbirine benzerdir. Ayrıca bu araştırmada kullanılan ölçekte yer alan "genel kültür" alt boyutuna ait ifadelerin ortalaması, diğer alt boyutlara kıyasla daha yüksek bulunmuş ve öğretmen adaylarının görüşleri doğrultusunda ideal bir beden eğitimi öğretmenin sahip olması gereken özellikler arasında en önemlisi genel kültür bilgisi olarak belirlenmiştir. Araştırmanın bu bulgusu, Arnon ve Reichel (2007) tarafından yapılan çalışma bulgusu ile paralellik göstermektedir.

Beden eğitimi öğretmenliği bölümünde öğrenim gören kadın ve erkek öğretmen adaylarının ideal beden eğitimi öğretmeninin sahip olması gereken nitelikler açısından görüşlerinin farklılaşmadığı belirlenmiştir. Bir başka deyişle kadın ve erkek ögretmen adaylarının ideal bir beden eğitimi öğretmeninin sahip olması gereken nitelikler ile ilgili düşünceleri birbirine benzerdir. Çalışmanın bu bulgusu Kelly (2007)'nin yapmış olduğu çalışma bulgusu ile paralellik gösterirken; Çoban, Devecioğlu, Aysan ve Zirek (2009) ve Çakmak (2009)'ın yapmış olduğu çalışma bulgusu ile farklılık göstermektedir. Çoban, Devecioğlu, Aysan ve Zirek (2009) cinsiyet değişkenine göre, öğrencilerin ideal beden eğitimi öğretmeninin niteliklerine ilişkin görüşleri arasında kadın ve erkek öğrenciler arasında istatistiksel olarak anlamlı bir farklılık elde etmişlerdir. Yapılan araştırmanın sınıf öğretmeni adayları üzerinde yürütülmüş olması araştırmalar arasındaki bu farklılığa neden olmuş olabilir. Çakmak da (2009) öğretmen adaylarının etkili öğretmen nitelikleri konusundaki düşüncelerini belirlediği araştırmasında, kadın ve erkek öğretmen adayları arasında istatistiksel olarak anlamlı bir fark elde etmiştir. İki araştırma arasındaki bu farklılık, Çakmak'ın (2009) yapmış olduğu araştırmanın sayısal ve sözel alanlarda öğrenim gören öğretmen adayları üzerinde yürütülmesinden ve ideal beden eğitimi öğretmeni özelliklerini değil de genel olarak etkili öğretmenlik niteliklerini belirlemek amaçlı farklı bir ölçme aracı kullanılmış olmasından kaynaklanıyor olabilir.

Beden eğitimi öğretmeni adaylarının öğrenim gördükleri sınıf değişkeni açısından ideal beden eğitimi öğretmeni nitelikleri ile ilgili görüşleri karşılaştırıldığında ise Konu Alanı Hâkimiyeti: Bilişsel Boyut (Teorik) ve Konu Alanı Hâkimiyeti: Psikomotor Boyut (Uygulama) alt boyutlarında istatistiksel olarak anlamlı bir farka rastlanmıștır. İki alt boyutta oluşan bu farkın birinci ve dördüncü sınıfta öğrenim gören öğretmen adayları arasında dördüncü sınıflar lehine olduğu belirlenmiştir. Dördüncü sınıfta öğrenim gören öğretmen adaylarının birinci sınıfta öğrenim gören adaylara kıyasla ideal bir beden eğitimi öğretmeninin bilişsel ve psikomotor konu alanı hâkimiyetine daha fazla sahip olması gerektiğini belirtmişlerdir. Beden eğitimi öğretmenliği bölümünde birinci sınıfta öğrenim gören öğretmen adaylarının beden eğitimi alanına daha yeni giriş yapmaları, alanla ilgili teorik ve uygulamalı dersleri daha henüz pek fazla görmemeleri ve bu nedenle alanı daha tam anlamıyla tanımamaları nedeniyle bu fark ortaya çıkmış olabilir. Ayrıca dördüncü sınıfta öğrenim gören öğretmen adaylarının Özel Öğretim Yöntemleri, Okul Deneyimi ve Öğretmenlik Uygulaması gibi derslerde bilişsel ve psikomotor anlamda konu hâkimiyetinin etkili ders işleyebilmek için son derece gerekli olduğunu bizzat yaşayarak öğrenmeleri bu farkın diğer bir nedeni olarak gösterilebilir. Ayrıca çalışma bulgularına paralel olarak Demirhan, Coşkun ve Altay (2002) tarafından yapılan bir çalışmada da; beden eğitimi öğretmeni adayı dördüncü sınıf öğrencilerinin ideal bir beden eğitimi öğretmeninde 
bulunması gereken en önemli niteliğin "mesleki bilgi ve becerilerde yeterli olma" şeklinde belirledikleri tespit edilmiştir.

Çalışma bulgularına bakılarak öğretmen adaylarının üniversite öğrenimleri boyunca aldıkları derslerde ideal bir beden eğitimi öğretmenin sahip olması gereken nitelikleri son derece etkili olarak öğrendikleri sonucuna ulaşılmıştır. İdeal bir beden eğitimi öğretmeninin sahip olması gereken nitelikler konusunda öğrencilerin farkındalıklarının yüksek olması ileride mesleğe başladıklarında bilişsel, duyuşsal ve devinişsel anlamda bir bütün olarak gelişmiş öğrenciler yetiştirmeleri açısından son derece önemlidir. Beden eğitimi öğretmeni adayları üzerinde bu tür çalışmalar çeşitli aralıklarla yapılarak, adayların ideal bir beden eğitimi öğretmeninde bulunması gereken niteliklerin ne derece farkında oldukları belirlenmeli ve eğer gerekirse lisans dersleri içerikleri bu özelliklere daha fazla vurgu yapacak şekilde güncellenmeli ve öğretim elemanlarının da öğretmen adaylarına bu niteliklere dikkat ederek model olmaları önerilmektedir.

\section{Kaynakça}

Arnon, S. \& Reichel, N. (2007). Who is the ideal teacher? Am I? Similarity and difference in perception of students of education regarding the qualities of a good teacher and of their own qualities as teachers. Teachers and Teaching: Theory and Practice, 13(5), 441-464.

Başar, M. A. \& Coşkun, A. (2017). Secondary school students' opinions about physical education course.International Journal of Science Culture and Sport,5(4), 263-273.

Çakmak, M. (2009). Öğretmen adaylarının “etkili öğretmen" nitelikleri konusundaki düşünceleri. Eğitim ve Bilim,34(153), 74-82.

Çalışkan, M., Işık, A. N. \& Saygın, Y. (2013). Öğretmen adaylarının ideal öğretmen algıları. İlköğretim Online, 12(2), 575-584.

Çetin, Ş. (2001). İdeal öğretmen üzerine bir araştırma. Milli Eğitim Dergisi, 149.

Çoban, B., Devecioğlu, S., Aysan, H. A. \& Zirek, O. (2009). Eğitim fakültesi ilköğretim sınıf öğretmenliği bölümü ikinci sınıf öğrencilerinin ideal beden eğitimi öğretmeni niteliklerine ilişkin görüşleri. I. Uluslararası Ĕ̆itim Araştırmaları Kongresi, Çanakkale.

Çoban, B. \& Turan, M. (2006). Öğrenci görüşlerine göre ideal beden eğitimi öğretmeninin nitelikleri: Ölçek geliştirme çalışması. Fırat Üniversitesi Sosyal Bilimler Dergisi,16(1), 149-161.

Demirhan, G., Coşkun, H. \& Altay, F. (2002). Beden eğitimi öğretmenlerinin niteliklerine ilişkin görüşler. Eğitim ve Bilim, 27(123), 35-41.
Dinçer, T. (2012). Edirne ilinde görev yapan beden eğitimi ögretmenlerinin liderlik davranışlarının değerlendirilmesi. Yüksek Lisans Tezi. Edirne:Trakya Üniversitesi.

Erden, M. (1998). Öğretmenlik mesleğine giriş. İstanbul:Alkım Yayınları.

Karabulutlu, Z. \& Pulur, A. (2017). Beden eğitimi öğretmenlerinin mesleki yeterliği ve eğitimlerinin özel alan yeterliklerine etkisinin incelenmesi.Spormetre, 15(3), 171-178.

Karasar, N. (2013). Bilimsel araştırma yöntemi. 25. Basım. Ankara: Nobel Akademik Yayıncılık.

Kelly, S. N. (2007). High school band students' perceptions of effective teaching. Journal of Band Research, 42(2), 57-70.

Komarraju, M. (2013). Ideal teacher behaviors: Student motivation and self-efficacy predict preferences.Teaching of Phychology, 40(2), 104-110. doi: $10.1177 / 0098628312475029$

Kosgei, A., Jairo, M. K., Odera, O.\& Ayugi, M. E. (2013). Influence of teacher characteristics on students' academic achievement among secondary school. Journal of Education and Practice,4(3), 76-82.

MEB (2017).Öğretmenlik Mesleki Genel Yeterlikleri. Öğretmen Yetiştirme ve Geliştirme Genel Müdürlüğü, Ankara.

Milli Eğitim Temel Kanunu 1973,Yayımlandığı R.Gazete: 14574, Yayımlandığ 1 Düstur: 5(12); 2342 (24.06.2012).

Saçlı, F., Bulca, Y., Demirhan, G. \& Kangalgil, M. (2009). Beden eğitimi öğretmenlerinin kişisel nitelikleri. Spor Bilimleri Dergisi, 20(4), 145-151.

Solakumur, A., Kul, M., Ünlü, Y. \& Mülhim, M. A. (2017). Beden eğitimi ve spor öğretmenlerinin yansıtıcı düşünme eğilimlerinin ve yansıtma yeteneklerinin bazı demografik değişkenlere göre incelenmesi.Uluslararası Kültürel ve Sosyal Araştırmalar Dergisi, 3(Special Issue 2), 294-307.

Taşkaya, S. M. (2012). Nitelikli bir öğretmende bulunması gereken özelliklerin öğretmen adaylarının görüşlerine göre incelenmesi. Erciyes Üniversitesi Sosyal Bilimler Enstitüsü Dergisi, 33(2), 283-298.

Walker, R. J. (2008). Twelve characteristics of an effective teacher: A longitudinal, qualitative, quasi-research study of in-service and pre-service teachers' opinions. Educational Horizons, 87(1), 61-68.

Yıldırım, A. \&Şimşek, H. (2005). Sosyal bilimlerde nitel araştırma yöntemleri. Ankara: Seçkin Yayıncılık. 